\title{
MODELING OF MECHENICAL BEHAVIOR OF REINFORCED CONCRETE BEAM REINFORCED BY THE SHAPE MEMORY ALLOY INSERTION USING FINITE ELEMENTS METHOD
}

\author{
МОДЕЛЮВАННЯ МЕТОДОМ СКІНЧЕНИХ ЕЛЕМЕНТІВ \\ МЕХАНІЧНОЇ ПОВЕДІНКИ ЗАЛІЗОБЕТОННОЇ БАЛКИ, \\ ПІДСИЛЕНОЇ ВСТАВКАМИ ЗІ СПЛАВУ ПАМ'ЯТІ ФОРМИ
}

Bykiv N.Z., student, Yasniy P.V., T.Sc.D., professor, rector, Iasnii V.P., Ph.D., Associate Professor at the Department of Structural Mechanics (Ternopil Ivan Puluj National Technical University, Ternopil)

Биків Н.З., студент, Ясній П.В., д.т.н., професор, ректор, Ясній В.П., д.ф., доцент кафедри будівельної механіки (Тернопільський національний технічний університет імені Івана Пулюя, Тернопіль)

One of the methods for improving the bearing capacity of the construction structures and engineering constructions is the application of construction materials with the improved strength and flexibility characteristics as well as the ability to disperse the vibration energy. It is of particular importance for the construction structures being in the seismic regions, which are under dynamic loading during their operation. The shape Memory Alloys (SMA) are promising materials, which can recover their original shape after uploading (the effect of superelasticity) or being under the temperature influence (the effect of shape memory) during many cycles of loading - unloading.

The mechanical behavior of a reinforced concrete beam with classical reinforcement and a reinforced concrete beam reinforced with inserts of superelastic Nitinol (Ni-Ti) is simulated by the finite element method. Beam dimensions: $h=140 \mathrm{~mm}$; $b=80 \mathrm{~mm} ; L=1200 \mathrm{~mm}$. The beam is made of concrete of the C20/25 class, armature

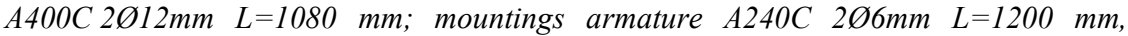
reinforcing insert $\mathrm{Ni}-\mathrm{Ti} 2 \varnothing 12 \mathrm{~mm} \mathrm{~L}=120 \mathrm{~mm}$. Behavior simulation took place in the ANSYS Workbench 19 R2 PC environment. Reinforced concrete beam is divided into finite elements. Size of the Solid 186 elements for the armature $12,5 \mathrm{~mm}$, for the mountings armature $40 \mathrm{~mm}$. The size of the Solid 186 elements for the body of the beam was automatically selected by the software $-200 \mathrm{~mm}$. In total, the reinforced concrete beam consisted of 22872 finite elements and 4730 nodes. Reinforced concrete beam with armature $A 400 C$ is subjected to evenly distributed load on the plane $120 \times 80 \mathrm{~mm}$ $(P=20 M P a)$. It is revealed that the transition of the yield strength in the simulated beam with armature $A 400 C$ occurs at a load of $P=9 M P a$. Therefore, the study of the behavior of the reinforced concrete beam with classical reinforcement (armature $A$ $400 C)$ and the reinforced concrete beam reinforced with inserts of superelastic Nitinol (Ni-Ti) occurred when loading beams to the value of $P=9 M P a$ and their complete unloading. The insert of nickel-titanium (Ni-Ti) alloy replaced the plastically deformed section of the working reinforcement $A 400 C$, where the stresses exceeded the yield strength $\left(\sigma_{t 0.2}=365 \mathrm{MPa}\right)$. 
The values of displacements, maximum stresses and residual stresses of the beams by compared. It was concluded that the inserts made of superelastic Ni-Ti alloy 16,9 times reduced the $\varepsilon_{\text {res }}$ of the working reinforcement, increased the maximum displacement of the beam by $9,7 \%$, increased the $\varepsilon_{\max }$ by $47,8 \%$ compared to the working reinforcement $A 400 C$.

Методом скінчених елементів змодельовано механічні поведінки залізобетонної балки із класичним армуванням та залізобетонної балки, підсиленої вставками із нікель-титанового сплаву (Ni-Ti) 3 ефектом надпружності. Розміри балки: $h=140$ мм; $b=80$ мм; L=1200 мм. Балка виконана із бетону класу C20/25, арматури 2012 A400C L=1080 мм; монтажної арматури 206 A240C L=1200 mm, підсилюючої вставки Ni-Ti 2Ø12мм L=120 мм. Моделювання поведінки відбувалося у середовищі ПК ANSYS Workbench 19 R2. Залізобетонну балку розділено на скінченні елементи. Розмір $3 D$ елементів Solid 186 для робочої арматури рівні 12,5 mm, для монтажної арматури Solid 186 - 40 мм. Розмір елементів Solid 186 для тіла балки програмне забезпечення підібрало автоматично - 200 мм. В загальному, залізобетонна балка складалася із 22872 скінченних елементів та 4730 вузлів. Залізобетонну балку із робочою арматурою А400С піддано рівномірно розподіленому навантаженню площиною $120 \times 80$ мм $(P=20 М П а)$. Виявлено, щуо перехід межі текучості у змодельованій балці із робочою арматурою $А 400 С$ відбувається при навантаженні $P=9 M П а$. Тому дослідження поведінки залізобетонної балки із робочою арматурою А400С та залізобетонної балки із вставками із нікель-титанового сплаву (Ni-Ti) з ефектом надпружності відбувалися при навантаженні балок до значення $P=9 M \Pi а$ та повному їх розвантаженні. Вставкою із нікель-титанового (Ni-Ti) сплаву замінено пластично деформовану ділянку робочої арматури A400C, де напруження перейтли значення межі текучості ( $\sigma_{t} 0.2=365$ МПа). Порівняно отримані максимальні та залишкові напруження та відносні видовження балок. Зроблено висновок, щео вставки із надпружного Ni-Ti сплаву у 16,9 разів зменшили $\varepsilon_{\text {res }}$ робочої арматури, на 9,7\% збільшили максимальний прогин балки, на 47,8\% збільшили $\varepsilon_{\max }$ порівняно із робочою арматурою А400С.

Ключові слова: сплав пам'яті форми, надпружність, підсилення конструкиії. Keywords: shape memory alloy, superelastic, reinforcement of the structure.

Statement of the problem. One of the methods for improving the bearing capacity of the construction structures and engineering constructions is the application of construction materials with the improved strength and flexibility characteristics as well as the ability to disperse the vibration energy. It is of particular importance for the construction structures being in the seismic regions, which are under dynamic loading during their operation. The shape Memory Alloys (SMA) are promising materials, which can recover their original shape after uploading (the effect of superelasticity) or being under the temperature influence (the effect of shape memory) during many cycles of loading - unloading. 
Analysis of the available results of investigation. The shape memory alloys (SMA) were discovered in late 60-s of the last century. One-sided and two-sided shape memory effects (SME), superelastic behavior (SE) were investigated. Due to high damping properties SMA are used as the main elements in the devices to decrease the dynamic loadings of the constructions structures [1-5] and engineering constructions, bridges in particular [6,7]. Besides, in the construction SMA are considered to be the alternative strengthening of the structures or their elements being in operation in the seismic regions. Thanks to the SE these alloys can recover after sufficient deformations (in some cases up to $10 \%$ ) under unloading, which results in the stable residual deformations during the steel alloying [8], [9-12].

Small reinforced concrete beams with the NiTi insertions were tested under the monotonic loading by the three-point displacement before fracture [13]. The behavior of conventional supporting reinforced beams with the hybrid reinforcement (steel reinforcement with NiTi insertions) and the control beam were tested experimentally. It was found, that the beam with SMA insertion being combined with the high-strength steel demonstrates improved crack recovery and deformation properties. That is why the application of the hybrid $\mathrm{NiTi}$ with steel can sufficiently decrease the risk of fracture under earthquakes as well as decrease the loses caused by it.

Taking into account sufficient material and labour expenditures to carry out similar full-scale experiments in order to optimize the reinforced structures the finite - elements method is worth being used for the modeling of the stressstrain state [14].

Objective of the work is to model and investigate the stress-strain state of the reinforced beam with the nickel-titanium alloy insertion with the superelasticity effect under monotonic loading and unloading from the loading distributed on the square $120 \times 80 \mathrm{~mm}$ using the finite elements method.

Statement of the task. The reinforced C25/30 concrete beam was chosen for the investigation (Fig. 1). The characteristics of the structure are: reinforced beam $\mathrm{b}=80 \mathrm{~mm}, \mathrm{~h}=140 \mathrm{~mm}, \mathrm{~L}=1200 \mathrm{~mm}$; reinforcement A400C $2 \varnothing 12 \mathrm{~mm}$; assembly reinforcement A240C $206 \mathrm{~mm}$.

Basic characteristics of mechanical properties of beam elements used for the modeling are presented on Table 1.

\begin{tabular}{|c|c|c|c|}
\hline Elements & $\sigma_{\mathrm{t} 0.2}, \mathrm{MPa}$ & $\sigma_{\mathrm{t} \max }, \mathrm{MPa}$ & $\mathrm{E}, \mathrm{GPa}$ \\
\hline $\mathrm{A} 400 \mathrm{C}$ & 365 & 460 & 210 \\
\hline $\mathrm{NiTi}$ & $450^{*}$ & $1200^{*}$ & $52,7^{*}$ \\
\hline $\begin{array}{c}\text { Concrete } \\
\mathrm{C} 20 / 25\end{array}$ & - & 2,2 & 23 \\
\hline
\end{tabular}

*Characteristics of the nitinol mechanical properties were found under the tensile strain at the temperature $18^{\circ} \mathrm{C}[15]$. 
Here $\sigma_{\mathrm{t} 0.2}$ - is the material yield limit under tension (for the Ni-Ti; alloy starting stress value for the forward phase transformation) $\sigma_{t \text { max }}-$ is the material tension strength limit; $\mathrm{E}$ - is the material 1-st level modulus of elasticity (the Young's modulus), (for the Ni-Ti alloy -austenite elasticity modulus).
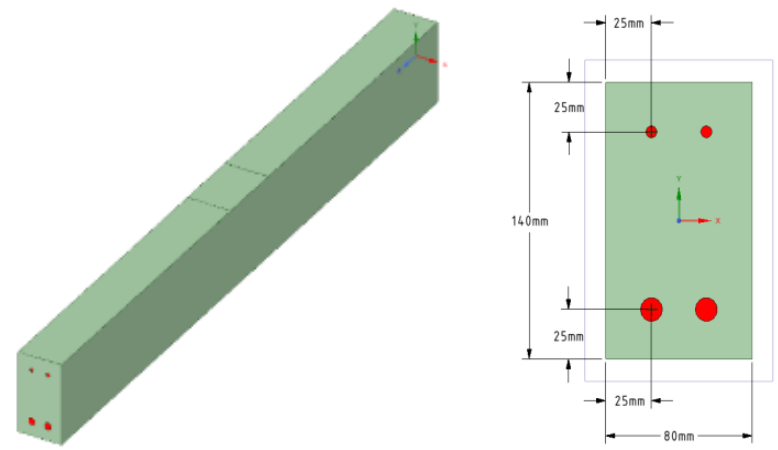

a)

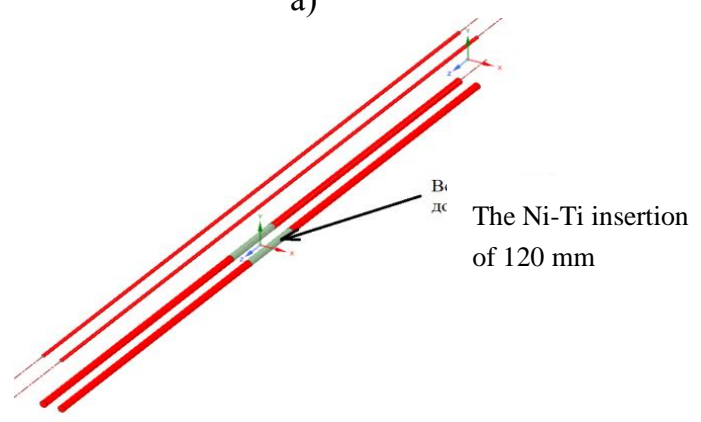

b)

Figure 1. The spatial model of reinforced concrete beam: a) the main view; b) the location of $\mathrm{Ni}$-Ti insertion

It should be noted, that the values of the conditional yield limit and the nitinol strength exceed sufficiently the corresponding characteristics of strength of the steel reinforcement A400C (Table 1).

The concrete strength data and that of the reinforcement meet the standards of ДБН В.2.6-98:2009 [16] and ДСТУ Б В.2.6-156:2010 [17].

All calculations of the free-support beam on two supports (Fig. 2,a) are performed for the force $P=9 \mathrm{MPa}$ being uniformly distributed in the area $\mathrm{D}$ of the $120 \times 80 \mathrm{~mm}$. The values of the force are chosen in such a way, that the stress on the operating reinforcement $\mathrm{A} 400 \mathrm{C}$ has exceeded the yield stress of the operating reinforcement $\mathrm{A} 400 \mathrm{C}\left(\sigma_{t 0,2}=365 \mathrm{MPa}\right)$. With this purpose the reinforced beam with the operating reinforcement A400C is loaded gradually up to the value $\mathrm{P}=20 \mathrm{MPa}$ (Fig.3). The force distributed in the area $\mathrm{D}$ is 
symmetric relatively the geometric center of the upper side and is directed to $\mathrm{Y}$. Besides, the force of gravity acting on the beam and directed to $-\mathrm{Y}$ is taken into account.

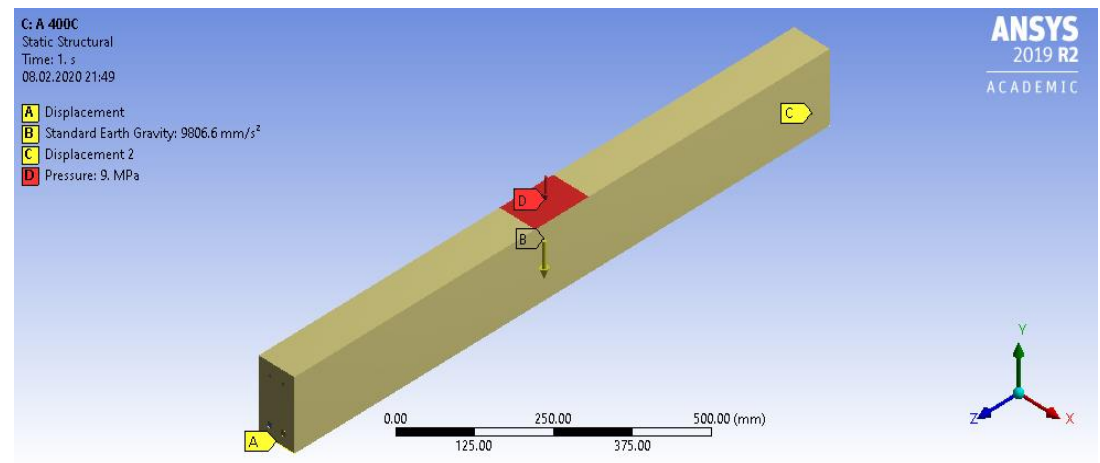

a)

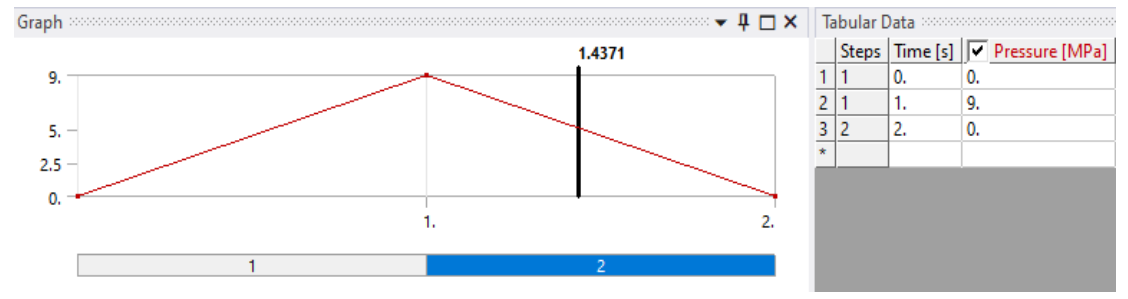

b)

Figure 2. The design scheme of the beam: a) freely supported state, where A and $\mathrm{C}$ are the locations of the beam support; B - application of gravity $\mathrm{g}=9.8066$ $\mathrm{m} / \mathrm{s}^{2}$ to the center of mass of the structure; $\mathrm{D}$ - the area of application of force $\mathrm{P}$ $=9 \mathrm{MPa} ; \mathrm{b}$ ) beam loading-unloading scheme

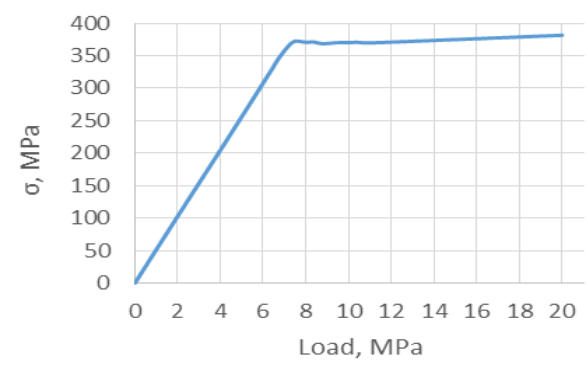

Figure 3. Dependence of stresses in the armature A 400C on the applied distributed loading 
The stress-strain state is modeled in the medium ANSYS 2019 R2. To calculate it all bodies of the reinforced beam are divided into finite elements. The size 3D of the Solid 186 elements for the operating reinforcement is equal to $12,5 \mathrm{~mm}$, for the mounting reinforcement Solid $186-40 \mathrm{~mm}$. The Solid 186 elements size for the beam body were selected automatically by the software being of $200 \mathrm{~mm}$. In general, the reinforced beam consisted of 22872 finite elements and 4730 units.

Analysis of data. In Fig. 4 the distribution of displacement (bending) fields in the beam with the operating reinforcement A400C (a) and with the SMA insertion (b) under the maximum loading, taking into account the beam weight, are presented.

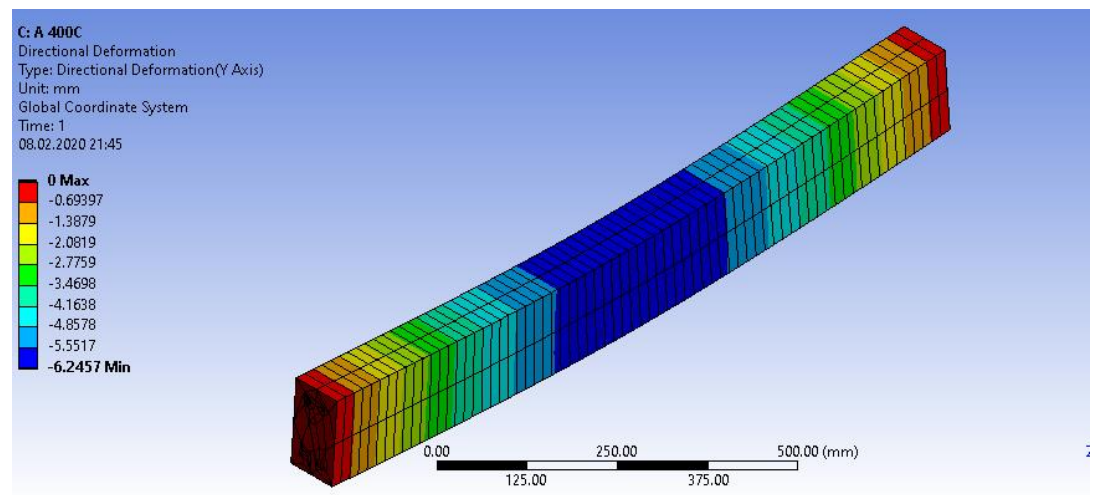

a)

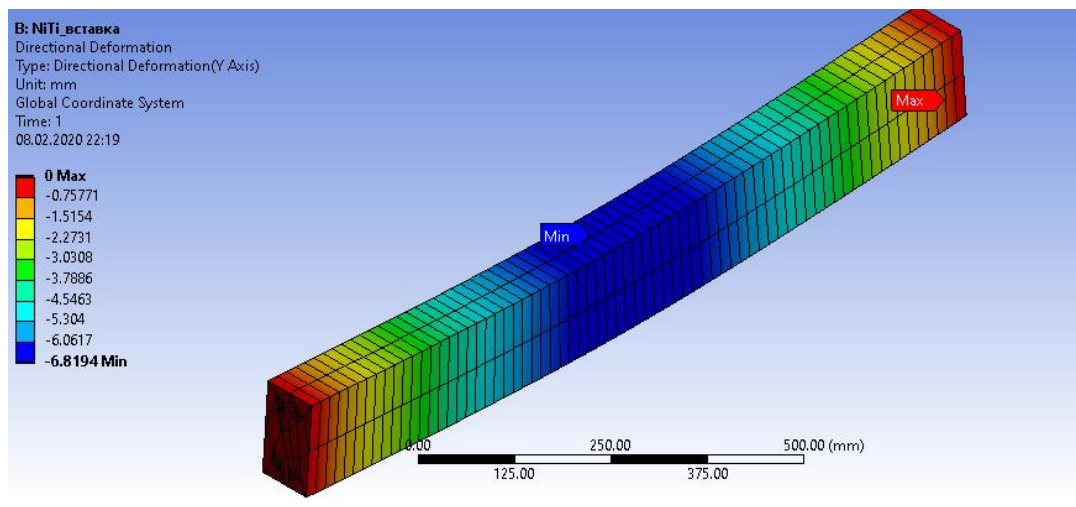

b)

Figure 4. The maximum displacement of beam: a) - with operating reinforcement bar A 400C; b) - with SMA insertion 
As it follows from the results analysis, the beam with the SMA insertion has been displaced by $9,2 \%$ more than that with the operating reinforcement 400C. It is caused by the less value of the NiTi modulus of elasticity in the area of deformation of austenite and in the area of austenite- martensite transformation as compared with that of the steel reinforcement and the superelastic behavior effect.

But after unloading the residual displacements of the beams with the operating reinforcement $400 \mathrm{C}$ (a) and that with the SMA insertion (b) are, in fact, the same.

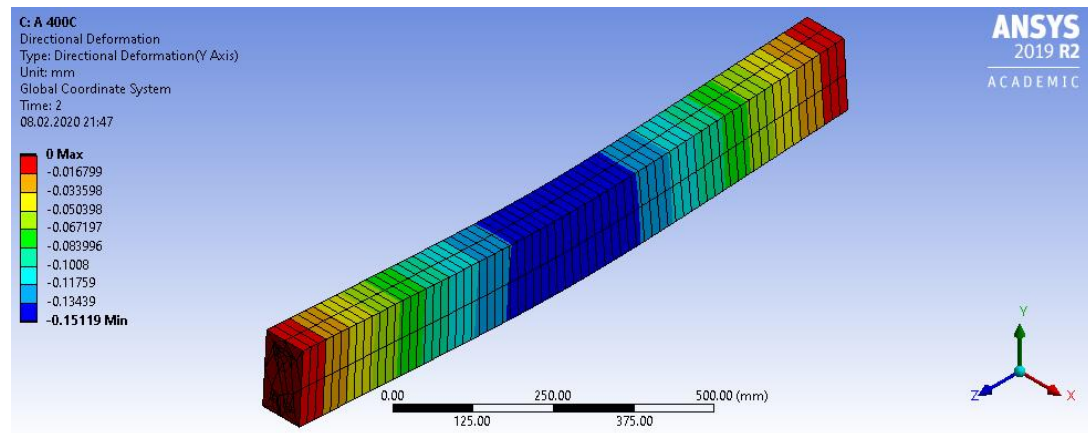

a)

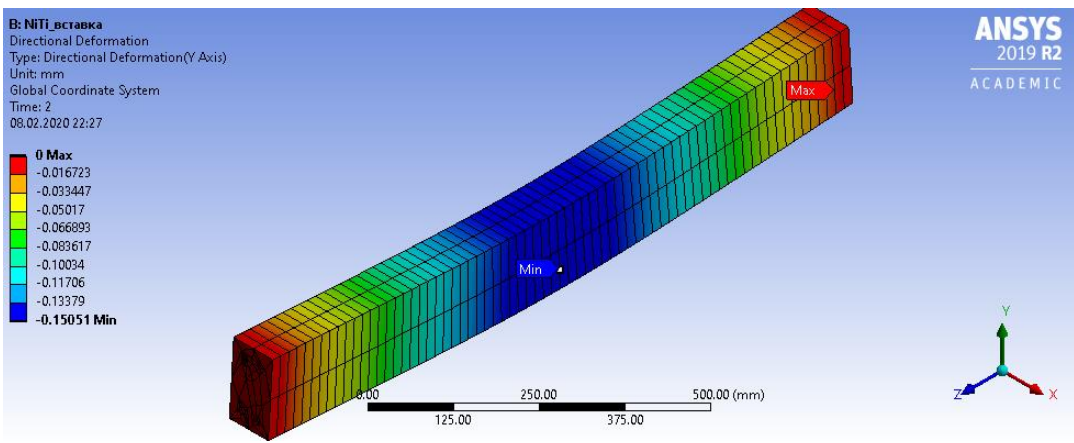

Figure 5. Residual displacement of beam after unloading: a) - with the operating armature bar A 400C; b) - with SMA insertion

The stresses and relative elongation along the axis of the operating reinforcement are presented in Fig. 6 and 7 correspondingly. In Fig. 6 it is seen, that the stress state in the SE insertion Ni-Ti alloy is sufficiently smaller (by $69,3 \%$ ) than that of the reinforcement A 400C. It is caused by the fact, that the reinforcement A $400 \mathrm{C}$ is of greater stiffness than that of the Ni-Ti alloy. Besides, it is seen, that when SMA insertion is used, the residual stress in the 
operating reinforcement after unloading decreases in 12,5 times as compared with that of the operating reinforcement A 400C.

It is seen in Fig. 7, that deformations in the operating reinforcement with the SE Ni-Ti alloy insertions are greater by $18,2 \%$ than those in the conventional operating reinforcement A 400C. This behavior is caused by the fact, that the reinforcement A $400 \mathrm{C}$ is of greater stiffness than that of the Ni-Ti alloy. The residual deformations in the operating reinforcement with the SE insertions, in fact, are not available. Due to it the crack "treatment" in the reinforced beam with the SE insertions takes place [13].

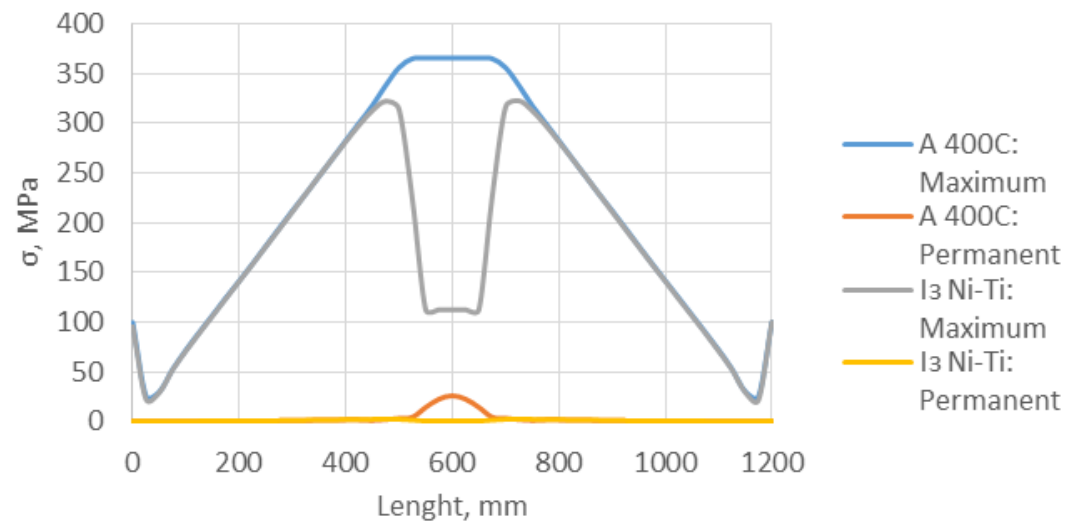

Figure 6. Stress distribution along reinforcement axis at $\mathrm{P}=9 \mathrm{MPa}$

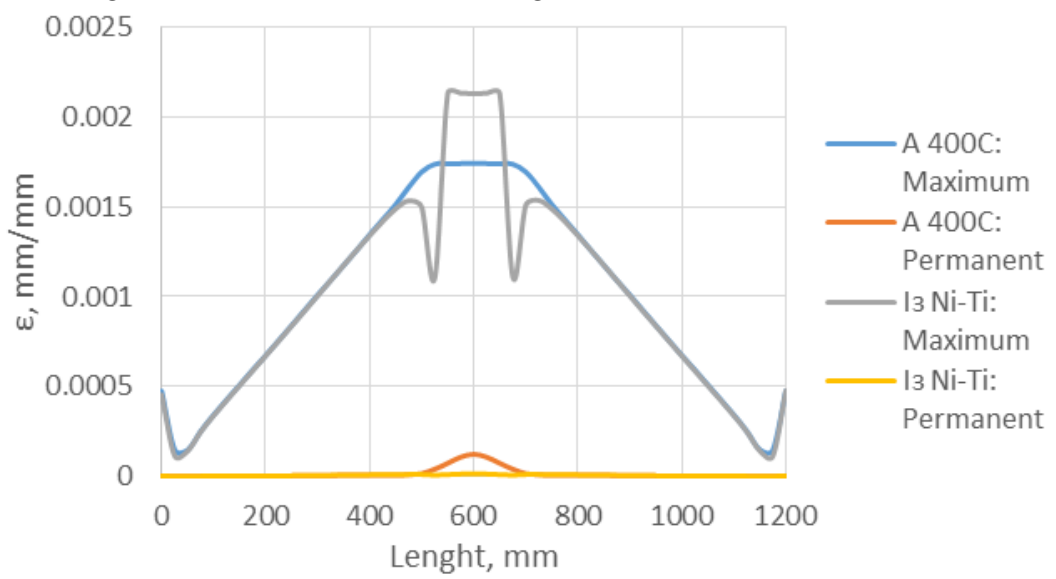

Figure 7. Strain distribution along the reinforcement axis after unloading

The obtained results of the digital modeling of the stress-stain state are presented on Table 2 and in Fig. 8. 
Table 2

The values of displacements, maximum stresses and residual stresses obtained by FEM

\begin{tabular}{|c|c|c|c|c|c|}
\hline $\begin{array}{c}\text { The main } \\
\text { reinforcement } \\
\text { bars }\end{array}$ & $\begin{array}{c}\text { Maximum } \\
\text { displacement, } \\
\mathrm{mm}\end{array}$ & $\begin{array}{c}\varepsilon_{\max }, \\
\mathrm{mm} / \mathrm{mm}\end{array}$ & $\begin{array}{c}\sigma_{\max }, \\
\mathrm{MPa}\end{array}$ & $\begin{array}{c}\varepsilon_{\text {res }}, \\
\mathrm{m} / \mathrm{m}\end{array}$ & $\sigma_{\text {res }}, \mathrm{MPa}$ \\
\hline A 400C & 6,25 & $1,76 \mathrm{e}-3$ & 370,25 & $3,66 \mathrm{e}-4$ & 76,80 \\
\hline $\begin{array}{c}\text { The insertion } \\
\text { of SMA }\end{array}$ & 6,82 & $2,61 \mathrm{e}-3$ & 377,63 & $2,16 \mathrm{e}-5$ & 3,64 \\
\hline
\end{tabular}

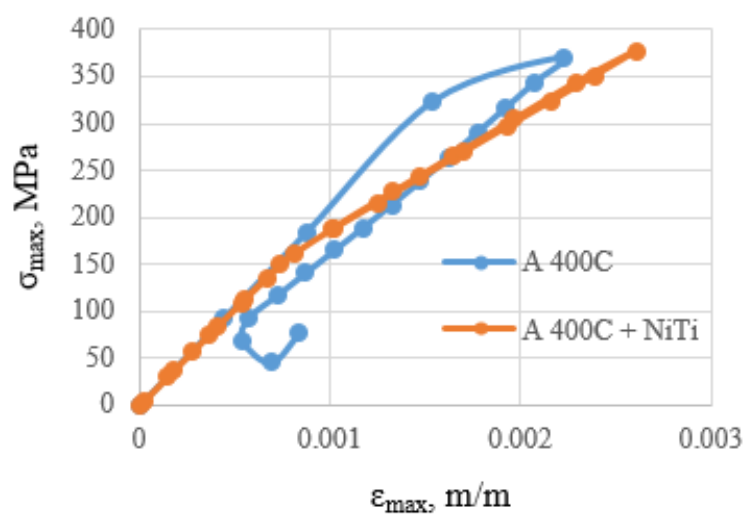

Figure 8. Stress-strain response for reinforced reinforcement

Having analyzed the obtained data it can be concluded:

Displacement of the beam with the SMA insertion under the maximum loading exceeds by $9,2 \%$ that with the operating reinforcement $400 \mathrm{C}$. The maximum relative elongation of the sample with the SMA insertion is by $47,8 \%$ greater than that of the sample without insertion. It is caused by the smaller SMA stiffness as compared with that of the conventional reinforcement.

The value of the maximum similar stress in the beam with the SMA insertion equals the stress in the beam without insertion. But the SMA insertion in the reinforcement decreases the maximum residual stresses by $4,7 \%$ as compared with those conventional ones.

Conclusions. The stress-strain stress of the conventional reinforced beam and that on two supports with the SMA superelastic alloy bar insertions of 120 $\mathrm{mm}$ length and the displacement, the loading being uniformly distributed in the central area, has been modeled using the finite-elements method and the ANSYS complex. The efficiency of the method for the decrease of stresses in the operating reinforcement and the replacement of the area, where the stresses exceed the material yield limit on the SMA SE insertion, has been interpreted. The SMA SE insertions of $12 \mathrm{~mm}$ diameter decrease in 16,9 times the 
maximum residual relative elongation of the operating reinforcement as compared with that of the operating reinforcement 400C.

According to the results of the stress-strain state modeling the increase of displacement by $9,2 \%$ of the beam with the SMA SE insertions was revealed as compared with that of the operating reinforcement $400 \mathrm{C}$, as well as the increase by $47,8 \%$ of the maximum relative elongation of the SMA SE reinforcement under the maximum loading.

\section{References}

1. Menna C., Auricchio F., Asprone D. Applications of shape memory alloys in structural engineering // Shape Memory Alloy Engineering. 2015. 369-403 p.

2. Isalgue A. et al. SMA for Dampers in Civil Engineering // Mater. Trans. 2006. Vol. 47, № 3. P. 682-690.

3. Silva P., Almeida J., Guerreiro L. Semi-active Damping Device Based on Superelastic Shape Memory Alloys // Structures. Elsevier B.V., 2015. Vol. 3. P. 1-12.

4. Ozbulut O.E., Hurlebaus S. Re-centering variable friction device for vibration control of structures subjected to near-field earthquakes // Mech. Syst. Signal Process. 2011.

5. Torra V. et al. The SMA: An Effective Damper in Civil Engineering that Smoothes Oscillations // Mater. Sci. Forum. 2012. Vol. 706-709, № July 2015. P. 2020 2025.

6. Fang C. et al. Superelastic NiTi SMA cables: Thermal-mechanical behavior, hysteretic modelling and seismic application // Eng. Struct. 2019. Vol. 183. P. 533-549.

7. Ai-Rong L. et al. A Method of Reinforcement and Vibration Reduction of Girder Bridges Using Shape Memory Alloy Cables // Int. J. Struct. Stab. Dyn. 2017. Vol. 17, № 7. P. 6-23.

8. Song G., Ma N., Li H.-N. Applications of shape memory alloys in civil structures // Eng. Struct. 2006. Vol. 28. P. 1266-1274.

9. Alam M.S., Youssef M.A., Nehdi M. Utilizing shape memory alloys to enhance the performance and safety of civil infrastructure: a review // Can. J. Civ. Eng. 2007. Vol. 34, № 9. P. 1075-1086.

10. Kolisnyk M.B. Sobashek L. Yasnii V.P. Obhruntuvannia vykorystannia SPF splaviv u dempfuiuchykh prystroiakh // Zbirnyk Tez Dopovidei VII Mizhnarodnoi Naukovo-tekhnichnoi Konferentsii Molodykh Uchenykh Ta Studentiv „Aktualni Zadachi Suchasnykh Tekhnolohii“. 2018. Vol. 1. P. 35.

11. Van Humbeeck J. Non-medical applications of shape memory alloys // Mater. Sci. Eng. A. Elsevier, 1999. Vol. 273-275. P. 134-148.

12. Song G., Ma N., Li H.N. Applications of shape memory alloys in civil structures // Eng. Struct. 2006. Vol. 28, № 9. P. 1266-1274.

13. Hamid N.A. et al. Behaviour of smart reinforced concrete beam with super elastic shape memory alloy subjected to monotonic loading // AIP Conf. Proc. 2018. Vol. 1958.

14. Hamid N.A. et al. Finite element analysis of smart reinforced concrete beam with super elastic shape memory alloy subjected to static loading for seismic mitigation. 1958. P. 20033.

15. Iasnii V. et al. Experimental study of pseudoelastic NiTi alloy under cyclic loading // Sci. J. TNTU. 2018. Vol. 92, № 4. P. 7-12. 
16. DBN V.2.6-98:2009. Konstruktsii budynkiv i sporud. Betonni ta zalizobetonni konstruktsii. Osnovni polozhennia. 2011.

17. DSTU B V.2.6-156:2010. Konstruktsii budynkiv i sporud. Betonni ta zalizobetonni konstruktsii z vazhkoho betonu. Pravyla proektuvannia. 2010.

\section{Список використаної літератури}

1. Menna C., Auricchio F., Asprone D. Applications of shape memory alloys in structural engineering // Shape Memory Alloy Engineering. 2015. 369-403 p.

2. Isalgue A. et al. SMA for Dampers in Civil Engineering // Mater. Trans. 2006. Vol. 47, № 3. P. 682-690.

3. Silva P., Almeida J., Guerreiro L. Semi-active Damping Device Based on Superelastic Shape Memory Alloys // Structures. Elsevier B.V., 2015. Vol. 3. P. 1-12.

4. Ozbulut O.E., Hurlebaus S. Re-centering variable friction device for vibration control of structures subjected to near-field earthquakes // Mech. Syst. Signal Process. 2011.

5. Torra V. et al. The SMA: An Effective Damper in Civil Engineering that Smoothes Oscillations // Mater. Sci. Forum. 2012. Vol. 706-709, № July 2015. P. 20202025.

6. Fang C. et al. Superelastic NiTi SMA cables: Thermal-mechanical behavior, hysteretic modelling and seismic application // Eng. Struct. 2019. Vol. 183. P. 533-549.

7. Ai-Rong L. et al. A Method of Reinforcement and Vibration Reduction of Girder Bridges Using Shape Memory Alloy Cables // Int. J. Struct. Stab. Dyn. 2017. Vol. 17, № 7. P. 6-23.

8. Song G., Ma N., Li H.-N. Applications of shape memory alloys in civil structures // Eng. Struct. 2006. Vol. 28. P. 1266-1274.

9. Alam M.S., Youssef M.A., Nehdi M. Utilizing shape memory alloys to enhance the performance and safety of civil infrastructure: a review // Can. J. Civ. Eng. 2007. Vol. 34, № 9. P. 1075-1086.

10. Колісник М.Б., Собашек Л., Ясній В.П. Обгрунтування використання СПФ сплавів у демпфуючих пристроях // Збірник тез доповідей VII Міжнародної науково-технічної конференції молодих учених та студентів „Актуальні задачі сучасних технологій“. 2018. Vol. 1. Р. 35.

11. Van Humbeeck J. Non-medical applications of shape memory alloys // Mater. Sci. Eng. A. Elsevier, 1999. Vol. 273-275. P. 134-148.

12. Song G., Ma N., Li H.N. Applications of shape memory alloys in civil structures // Eng. Struct. 2006. Vol. 28, № 9. P. 1266-1274.

13. Hamid N.A. et al. Behaviour of smart reinforced concrete beam with super elastic shape memory alloy subjected to monotonic loading // AIP Conf. Proc. 2018. Vol. 1958.

14. Hamid N.A. et al. Finite element analysis of smart reinforced concrete beam with super elastic shape memory alloy subjected to static loading for seismic mitigation. 1958. P. 20033.

15. Iasnii V. et al. Experimental study of pseudoelastic NiTi alloy under cyclic loading // Sci. J. TNTU. 2018. Vol. 92, № 4. P. 7-12.

16. ДБН, В.2.6-98:2009. Конструкції будинків i споруд. Бетонні та залізобетонні конструкції. Основні положення. 2011

17. ДСТУ Б В.2.6-156:2010. Конструкції будинків і споруд. Бетонні та залізобетонні конструкції з важкого бетону. Правила проектування. 2010. 